\title{
Theoretical and Practical Approaches to Environmental Performance
}

\author{
Teodor Hada \\ Bogdan Vodă University, Cluj Napoca, România \\ teohada@yahoo.com \\ Nicoleta Bărbuță-Mișu \\ Dunărea de Jos University of Galați, România \\ misunicoleta@yahoo.com \\ Teodora Maria Avram \\ 1 Decembrie 1918 University, Alba Iulia, România \\ avram teodora@ymail.com
}

\begin{abstract}
Currently, governments, companies, communities and individuals are aware that environment needs more consideration and some investments should be done in protecting or restoring it. Most of these investments mean higher costs and lower profit for companies. In this paper we present the environmental performance measures taken by the company ENVIRON SA. The environmental policy of this company is established through the Environmental Management System set out in the Environmental Handbook. Analysing data of the company ENVIRON SA we found that the values of the indicators regarding the monitoring of waste management, conventionally clean wastewater discharged into the river and air environmental factors, register values of the period 2015-2017 that fall within the normal limits, which shows that Romanian companies make important efforts for realising an efficient environmental management.
\end{abstract}

\section{Introduction}

Environmental performance is very important to national level and in very general terms means to enforce measures that provide the protection of environmental factors: air, water, soil, ecosystems. This meaning covers a wide range of actions that could be examined in terms of efforts invested in performing them or the outcomes measured by environmental quality indicators (Bran et al., 2011).

Reducing environmental impact or restoring damaged ecosystems are, in most of the cases, resource intensive processes of the companies or governmental agency. From the companies point of view, stakeholders are increasingly concerned with the environmental performance of firms and use it to make decisions about their investments.

The environmental performance for organizations is defined in numerous ways: a commitment of organizations to preserve and protect their natural environment with its multidimensional characteristics, such as maintaining the quality of water, air, soil, etc. (Lober, 1996); the effects of business activities and products on the natural environment, such as resource consumption, waste generation and emissions (Gallego-Alvarez et al., 2014); the components of environmental performance, such as the minimization of pollutants, conserving resources, waste reduction, energy conservation, marketing of safe products and reporting potential risks, among others (Epstein, M.J., 1996) define also the environmental performance.

The production of the companies has two main outcomes: products and services, and wastes and residuals. The supply of the products and services satisfies the demand of households and other companies while at the same time provides income sources to households and tax revenues to governments (Halkos and Zisiadou, 2016). The waste and residuals has as a 
consequence the damage of the environment, i.e. the pollution caused by firms may adversely affect the viability of households and/or other companies (Evangelinos and Halkos, 2002).

The environmental performance is a complex issue based on (Ilinitch et al., 1998): internal systems measures - environmental performance enhancing organizational processes; external stakeholder relations measures - interactions between the company and its external constituencies; external impact measures - negative environmental externalities; and finally, internal compliance measures - compliance with laws and regulation.

\section{Environmental Performance: Concept and Measurement}

From the management perspective (Burja et al., 2009), there are two major systems considered as methods that allow the integration of the environmental protection into the daily life of the organizations: ISO 14001:2015 - Environmental Management Systems and EMAS the EU Eco-Management and Audit Scheme.

The International Standard ISO 14001:2015 specifies the requirements for an environmental management system that an organization can use to enhance its environmental performance, and helps an organization achieve the intended outcomes of its environmental management system, which provide value for the environment, the organization itself and interested parties. Consistent with the organization's environmental policy, the intended outcomes of an environmental management system include: enhancement of environmental performance of organization; fulfilment of compliance obligations; and achievement of environmental objectives.

The EMAS is a premium management instrument developed by the European Commission for companies and other organisations to evaluate, report, and improve their environmental performance. It is open to every type of organisation eager to improve its environmental performance, and spans all economic and service sectors, and is also applicable worldwide. Thus, EMAS stands for (National Agency for Environmental Protection - ANPM):

- performance: EMAS supports organisations in finding the right tools to improve their environmental performance. Participating organisations voluntarily commit to both evaluating and reducing their environmental impact;

- credibility: third party verification guarantees the external and independent nature of the EMAS registration process;

- transparency: providing publicly available information on an organisation's environmental performance is an important aspect of EMAS. Organisations achieve greater transparency both externally through the environmental statement and internally through employees' active involvement.

With EMAS, organisations can reduce the environmental impacts, strengthen legal compliance and employee involvement, and save resources and money.

Organizations, that by their activities influence the environment, must have a management system and evaluate their environmental performance according to the objectives established for environmental quality management. At the organization level, the "Environmental Handbook" is elaborated. This includes the environmental management system of each organization.

The key standard of the evaluation of environmental performance, at international level is the International Standard ISO 14031:2013 - Environmental Management -- Environmental Performance Evaluation -- Guidelines. Assessing environmental performance based on the principle of relevance, completeness, transparency, coherence and accuracy is a management process that uses key performance indicators to compare past and present environmental performance with its objectives.

The International Standard ISO 14031:2013 gives guidance on the design and use of environmental performance evaluation (EPE) within an organization. It is applicable to all 
organizations, regardless of type, size, location and complexity and does not establish environmental performance levels.

The guidance in ISO 14031:2013 can be used to support an organization's own approach to EPE, including its commitments to compliance with legal and other requirements, the prevention of pollution, and continual improvement.

At the level of Romania, the Green Business Index (GBI) is a multi-annual project of the Green Revolution Association, launched in 2010, with the objective of independent evaluation and improvement of the environmental performance of Romanian companies. GBI is the only tool by which any company in Romania can completely evaluate its performance in the management of the environment, free, independently and at the level of international demands, according to the latest edition of the ISO 14001 standard (Econet Romania). The GBI represents (GBI, 2017):

- a mechanism for monitoring and visibility of green initiatives in the Romanian business sector;

- an assistance and training tool for evaluating and improving environmental performance in the business environment;

- a helping instrument in compliance with legal or, as the case may be, corporate requirements, regarding corporate social responsibility transparency and reporting, including regarding compliance with the requirements of EU Directive 2014/95 (non-financial reporting).

We mention that after Romania's accession to the European Union for environmental protection, the Sectorial Operational Programme for the Environment (2007-2013) and Large Infrastructure Operational Programme (2014-2020) were approved, considering the national strategic objectives set out in the National Development Strategy for each period.

The environmental performance indicators used for assessment of the environmental performance of entities provide information related to the organization of significant aspects of this field and at the same time demonstrate the results of its environmental management programs.

In the ISO 14031:2013 standard the environmental performance indicators are divided into groups and individual groups provide organizations with various information (MatuszakFlejszman and Szyszka, 2016):

- environmental condition indicators (ECI) - provide information about the local, regional, national or global condition of the environment, for example: change of the groundwater level, time of resource recovery, level of soil erosion, statement of pollution in plant tissues, quality of air in the region, pollution intensity in the air from emission of motor vehicles, pollution intensity in the topsoil, average level of noise, ozone layer degradation, time of resource recovery, occurrence of illnesses among the population on the basis of epidemiological research on the local and regional scales, temperature of oceans etc.

- environmental performance indicators (EPI) - provide information about an organization's environmental performance, including:

- management performance indicators (MPI) - provide information about the management activities to influence an organization's environmental performance, for example: number of implemented initiatives related to preventing pollution, level of conformity with legal regulations, number of products for which dismantling, recycling or reuse is predicted, savings obtained through the reduction of resource use, costs related to fines, pro-environmental investment share (e.g. regarding cleaner technologies or process improvements) in the total investment funds, number of trained peoples in relation the number of people that should be trained, number of hours of environmental training per 1 employee, number of people trained among contractors, number of environmental improvements proposed by employees, reaction time in reference to environmental incidents, number of conducted audits to the number of planned audits etc.

- operational performance indicators (OPI) - provide information about the environmental performance of an organization's operational process, for example: amount of materials used per 1 piece of the product, electrical energy consumption per 1 piece of the product, amount of 
chemicals used per a kilogram of textiles used, water consumption per 1 employee/ 1 piece of the product, fuel consumption by a vehicle per 1 kilometer, amount of heating oil used per 1 manhour, amount of waste transferred to recycling, amount of water reused in the production process, amount of raw materials reused in the production process, weight of the packaging devoted to multiple use and recycling (e.g. pallets) in relation to the total weight of packing, weight of packaging per 1 piece of the product, amount of sewage, intensity of pollution in sewage, amount of the defined emission per 1 piece of the product, noise and heat emission, number of emergencies annually etc.

For companies it is important to invest in environment protection or in technologies friendly with the environment. The environment protection means also the payment of environment taxes. Thus, annually, companies register environment expenses and we propose as indicator for assessment the environment performance the share of environment expenses in sales $\left(\mathrm{w}_{\mathrm{EE}}\right)$ calculated with the following formula:

$$
\mathrm{w}_{\mathrm{EE}}=\frac{\text { Environment Expenses }}{\text { Sales }}
$$

According to the view of numerous authors, the indicators selected to measure environmental performance were used for different areas of manifestation of the environmental performance, as follows (Achim and Borlea, 2014):

- environment input zone- including indicators such as: environmental site planning, energy consumption, used materials, water consume;

- environment output zone, reflected by: climate change, oxygen deficiency in water systems, water waste, the regulatory compliance, environment report, environmental auditing activities;

- input and output zone involves combining certain input and output indicators when assessing environmental performance.

Usually, at the level of the companies, the management performance indicators appear referring to: implementation of policies and programs, compliance, financial performance, and relationship with the community (Lupu, 2008). Also, after the practical documentation, we found that the operational performance indicators refer to the following aspects: materials, energy, services that support the activities of the organization, physical utilities and equipment, supply and delivery, products, services provided by the organization, waste and emissions. On the other hand, the environmental status indicators refer to: air, water, soil, flora, fauna, human population, aesthetics, heritage and culture.

\section{Measures taken by ENVIRON SA for the environment performance}

Companies make important efforts in order to fulfil environment standards. In this paper we analyse the approach to environment performance of a company named here from confidentiality reasons as ENVIRON SA. This company has developed an Environmental Management System, set up in the form of an Environmental Handbook which includes: scope, normative references, terms and definitions, company contract, leadership, support, operation, performance evaluation, improvements and annexes, such as system policy of environmental management, organization chart, planning of the intervention and succession of processes, and checklist of changes.

The environmental manual of the ENVIRON SA presents in the structure of environmental performance assessment the following aspects:

- monitoring, measuring, analysing and evaluating: general, customer satisfaction, and analysis and evaluation;

- internal audit; 
- management analysis: general, input elements of management analysis, and output elements of management analysis.

The company ENVIRON SA has set its general environmental policy objectives, which are presented as follows:

- reducing and preventing air pollution and ensuring the protection of water sources;

- reduction of water losses recorded in work processes;

- providing the necessary organizational control and adequate resources for investments, as well as defending them in emergencies;

- reducing the consumption of raw materials, materials, fuel and energy, in order to reduce, manage and recover all the waste resulting from the processes existing in the company;

- implementation of a management system for environmental protection in accordance with the requirements of the ISO 14001 Reference Standard;

- management of toxic and dangerous substances; protection.

- applying the provisions of the European Directives in the field of environmental

\section{Analysis of the environmental performance to ENVIRON SA}

At the level of the company ENVIRON SA, the environmental protection expenditures in the period $2015-2017$ have evolved as follows:

Table 1. Expenditure on environmental protection

\begin{tabular}{|l|c|r|r|r|}
\hline Indicator & $\begin{array}{c}\text { Measurement } \\
\text { unit }\end{array}$ & \multicolumn{1}{c|}{$\mathbf{2 0 1 5}$} & \multicolumn{1}{c|}{$\mathbf{2 0 1 6}$} & \multicolumn{1}{c|}{$\mathbf{2 0 1 7}$} \\
\hline $\begin{array}{l}\text { Expenditure of } \\
\text { environmental protection }\end{array}$ & EUR & $80,175.93$ & $70,448.57$ & $79,255.32$ \\
\hline Total expenses & EUR & $21,126,902.20$ & $18,788,115.43$ & $19,086,122.93$ \\
\hline Net turnover & EUR & $21,888,915.68$ & $18,704,595.80$ & $19,520,121.25$ \\
\hline$\%$ in Total expenses & $\%$ & $0.379 \%$ & $0.375 \%$ & $0.415 \%$ \\
\hline$\%$ in Net turnover & $\%$ & $0.366 \%$ & $0.377 \%$ & $0.406 \%$ \\
\hline
\end{tabular}

Source: Own processing based on the accounting evidence of ENVIRON SA.

Analysing the data presented in Table 1 we can conclude that the expenditure of environmental protection registered a fluctuating trend, i.e. decreasing with $12.13 \%$ in 2016 compared to 2015 and increasing to $12.50 \%$ in 2017 compared to 2016 . Also, related to the share of expenditure of environmental protection in total expenses registered also a fluctuating trend and values very low (lower than 1\%), i.e. between $0.375 \%$ in 2016 and $0.415 \%$ in 2017 . Regarding the share of expenditure of environmental protection in net turnover we observe a slightly upward trend from $0.366 \%$ in 2015 to $0.406 \%$ in 2017. analysed:

In addition to this analysis, the following environmental performance indicators were also

\section{A. Operational performance indicators on materials and energy}

Operational performance indicators are those indicators that provide information on the environmental performance of the company's activity. The level of the indicators regarding resources and production for the period 2015 - 2017 is presented in Table 2. The company keeps track of the consumption of raw materials and auxiliary materials on each production section: foundry, modelling and sketching. The storage and storage mode is the one provided in the integrated environmental authorization. 
Table 2. Consumption of resources related to the production achieved

\begin{tabular}{|l|l|r|r|r|}
\hline $\begin{array}{l}\text { Resources / } \\
\text { Production }\end{array}$ & $\begin{array}{l}\text { Measurement } \\
\text { unit }\end{array}$ & $\mathbf{2 0 1 5}$ & \multicolumn{1}{c|}{$\mathbf{2 0 1 6}$} & \multicolumn{1}{c|}{$\mathbf{2 0 1 7}$} \\
\hline Electricity & MWh & $25,323.216$ & $23,068.224$ & $24,979.992$ \\
\hline Natural gas & Ncm (Normal cm) & $1,258,433.00$ & $1,086,562.00$ & $993,143.00$ \\
\hline Technological water & Cubic meter $(\mathrm{cm})$ & $28,082.00$ & $28,316.00$ & $29,358.00$ \\
\hline Drinking water & Cubic meter $(\mathrm{cm})$ & $69,768.00$ & $54,461.00$ & $45,053.00$ \\
\hline Production of castings & Tons & $15,713.00$ & $13,473.00$ & $14,506.00$ \\
\hline
\end{tabular}

Source: Own processing based on the accounting evidence of ENVIRON SA.

Analysing the consumption of resources compared to the production achieved we can observe that production decreased to $14.26 \%$ in 2016 compared to 2015, and the same trend were registered for electricity (decrease to 8.90\%), natural gas (decreased to $13.66 \%$ ) and drinking water (decreased to $21.94 \%$ ), while the consumption of technological water increase to $0.83 \%$. The production increased to 7.67\% in 2017 compared with 2016, and a similar trend was registered only for electricity (increased to 8.28\%) and technological water (increased to 3.68\%), while the consumption of natural gas and drinking water decreased to $8.60 \%$ and respectively $17.27 \%$, which shows an efficient use of these resources.

\section{B. Operational indicators on waste}

There is a separate chapter in waste management in the Environmental Management System developed by the company analysed. Waste is defined in the Environmental Manual on ENVIRON SA as "any substance or object in the European catalogue of waste that the owner discards", and waste management involves "collection, transport, recovery of waste, including supervision of storage areas after closure."

From the reported data (Annex 1), the company ENVIRON SA manages a number of more than 30 wastes, of which a significant share is represented by the sand used for foundry, ferrous iron sheet and municipal waste.

The revenues from waste recovery are presented in Table 3 in comparison with the net turnover of the company.

Table 3. Revenue from waste recovery

\begin{tabular}{|l|c|r|r|r|}
\hline Indicator & $\begin{array}{c}\text { Measurement } \\
\text { unit }\end{array}$ & $\mathbf{2 0 1 5}$ & \multicolumn{1}{c|}{$\mathbf{2 0 1 6}$} & \multicolumn{1}{c|}{$\mathbf{2 0 1 7}$} \\
\hline $\begin{array}{l}\text { Revenue from waste } \\
\text { recovery }\end{array}$ & EUR & $7,942.76$ & $3,496.73$ & $7,066.98$ \\
\hline Net turnover & EUR & $21,888,915.68$ & $18,704,595.80$ & $19,520,121.25$ \\
\hline$\%$ in Net turnover & $\%$ & $0.036 \%$ & $0.019 \%$ & $0.036 \%$ \\
\hline
\end{tabular}

Source: Own processing based on the accounting evidence of ENVIRON SA.

Analysing the data presented in Table 3 we can conclude that the revenue from waste recovery registered a fluctuating trend, i.e. decreasing with 55.81\% in 2016 compared to 2015 and increasing by 2.07 times in 2017 compared to 2016. Also, related to the share of revenue from waste recovery in net turnover registered also a fluctuating trend and values very low (lower than $1 \%$, i.e. $0.019 \%$ in 2016 and $0.036 \%$ in 2015 and 2017.

\section{Quality indicators for conventional wastewater}

The level of these indicators is presented in Annex 2 for the period 2015-2017. From the data presented in this annex where the reference documents and the measured values were analysed, it follows that they fall within the limits of the allowable values, in all months of the year. 


\section{Indicators regarding the monitoring of environmental factors}

The indicators for monitoring the air environment factor, including the flue gas, are presented in Annex 3 and 4 and refer to: the source of pollution, the emission point, the imposed limit, the determined values, the frequency and the date of sampling of the processes. Analysing all data presented in Annex 3 and 4 for the period 2015-2017 we found that they fall within the limits of the allowable values.

\section{Conclusions}

Following the findings, it turns out that the values of the indicators regarding the monitoring of waste management, of conventionally clean wastewater discharged into the river and of environmental factors, register values of the period 2015-2017 that fall within the normal limits.

The environmental policy of the analysed company is established through the Environmental Management System set out in the Environmental Handbook, with which they make reports to users of environmental information. Although the valorisation of the recovered waste is quite small, the company ENVIRON SA annually incurs expenses with environmental protection of over 70,000 Euro.

However, from the reports made by the company through the indicator system, it turns out that the analysed company is not a polluting one because the emissions fall within the admitted limits established by the normative acts. This show that Romanian companies make important efforts for realising of an efficient environmental management.

\section{References}

1. Acbim, M. V., Borlea, S. N. (2014). Environmental performances - way to boost up financial performances of companies, Environmental Engineering and Management Journal, Vol. 13, No. 4, pp. 1003-1016.

2. Bran, F., Radulescu, C. V., Ioan, I. (2011). Review of International Comparative Management, Vol. 12, Issue 5, pp. 893-900.

3. Burja, V., Burja, C., Voicu, E. V. (2009). Environmental Performance Management in Agricultural Holdings, Bulletin UASVM Horticulture, Vol. 66, Issue 2, pp. 70-75.

4. Epstein, M. J. (1996). Measuring Corporate Environmental Performance; IMA/McGraw Hill: San Francisco, CA, USA.

5. Evangelinos, K., Halkos, G. (2002). Implementation of environmental management systems standards: important factors in corporate decision making. Journal of Environmental Assessment Policy and Management, Vol. 4, Issue 3, pp. 311-328.

6. Gallego-Alvarez, I., Vicente-Galindo, M. P., Galindo-Villardón, M. P., Rodríguez-Rosa, M. (2014). Environmental Performance in Countries Worldwide: Determinant Factors and Multivariate Analysis. Sustainability, Vol. 6, pp. 7807-7832.

7. Halkos, G., Zisiadou, A. (2016). Environmental performance index and economic welfare, MPRA Paper No. 75561, posted 13 December 2016, available at https:// mpra.ub.uni-muenchen.de/75561/.

8. Ilinitch, A. Y., Soderstorm, N. S., Thomas, T. E. (1998) Measuring corporate environmental performance. Journal of Accounting and Public Policy, Vol. 17, Issue 4-5, pp. 383-408.

9. Lober, D. J. (1996). Evaluating the environmental performance of corporations. Journal of Managerial Issues, Vol. 8, No. 2, pp. 184-205.

10. Lupu, L. (2008). Sistemul de indicatori de performanta de mediu, Tehnopress Publishing House, Bucharest.

11. Matuszak-Flejszman, A., Syyszka, B. (2016). Environmental Performance of an Organization, Chapter in Process and Product Management - Economic and Environmental Aspects in Organization, Edited by Matuszak-Flejszman, A., Poznan University of Economics and Business Faculty of Commodity Science, Poznan.

12. *** ANPM. Despre EMAS, available at http://www.anpm.ro//despre_emas?inheritRedirect $=$ true, accessed on 02.05.2019. 
13. *** Econet Romania, GBI, barometru CSR în România, available at https://www.econetromania.com/ro/news/gbi-barometru-csr-in-romania-html/, accessed on 14.05.2019.

14. *** GBI, 2017. Report Green Business Index 2017, available at https://www.gbindex.ro/wpcontent/uploads/2018/03/Catalog_GBI_2017.pdf, accessed on 14.05.2019.

15. *** International Standard ISO 14001:2015 - Environmental Management Systems -- Requirements with Guidance for Use, available at https://www.iso.org/standard/60857.html, accessed on 10.05.2019.

16. *** International Standard ISO 14031:2013 - Environmental Management -- Environmental Performance Evaluation - Guidelines, available at https://www.iso.org/standard/52297.html, accessed on 15.05.2019.

17. *** The EU Eco-Management and Audit Scheme (EMAS), available at https://ec.europa.eu/environment/emas/, accessed on 13.05.2019. 


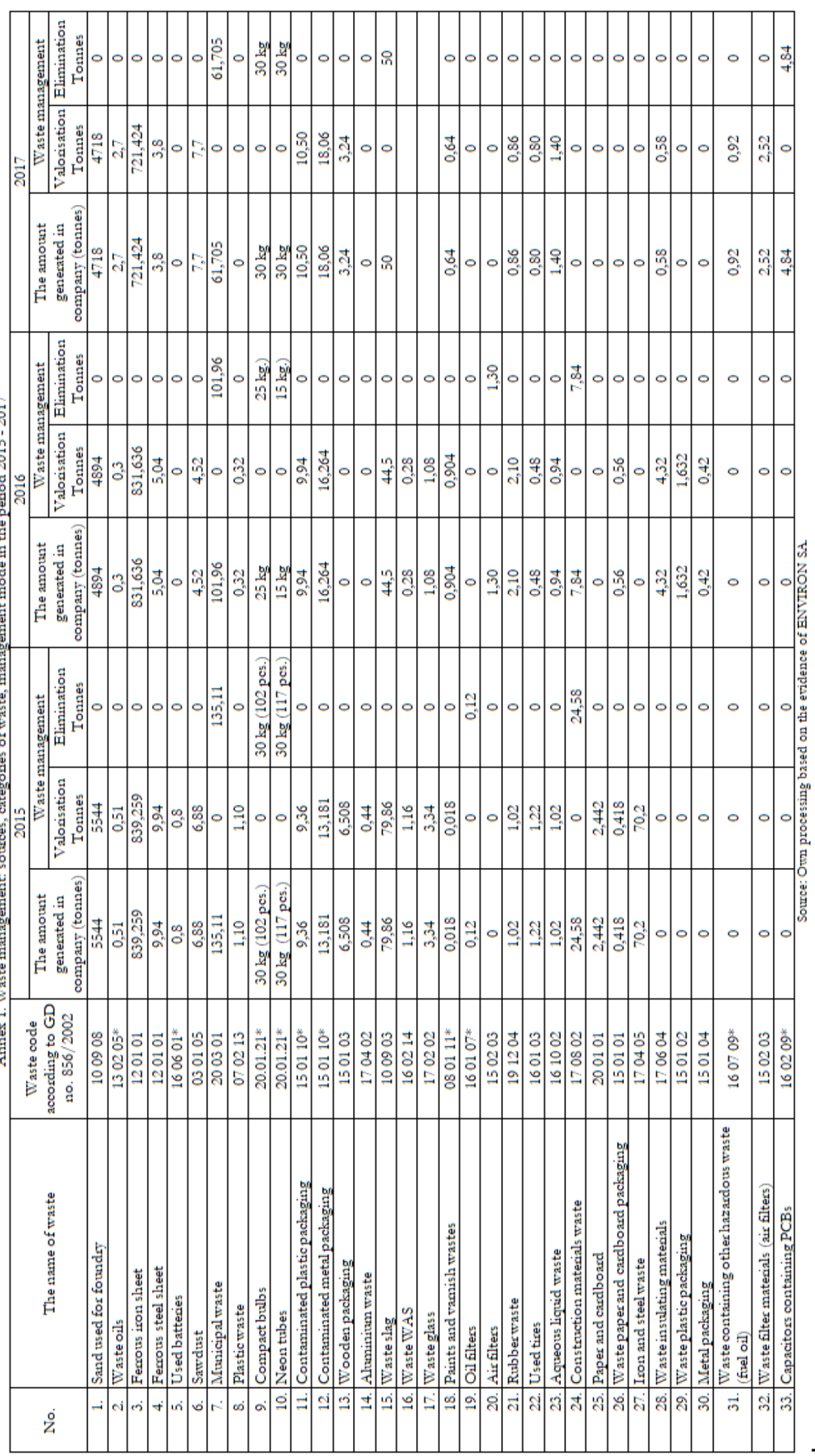




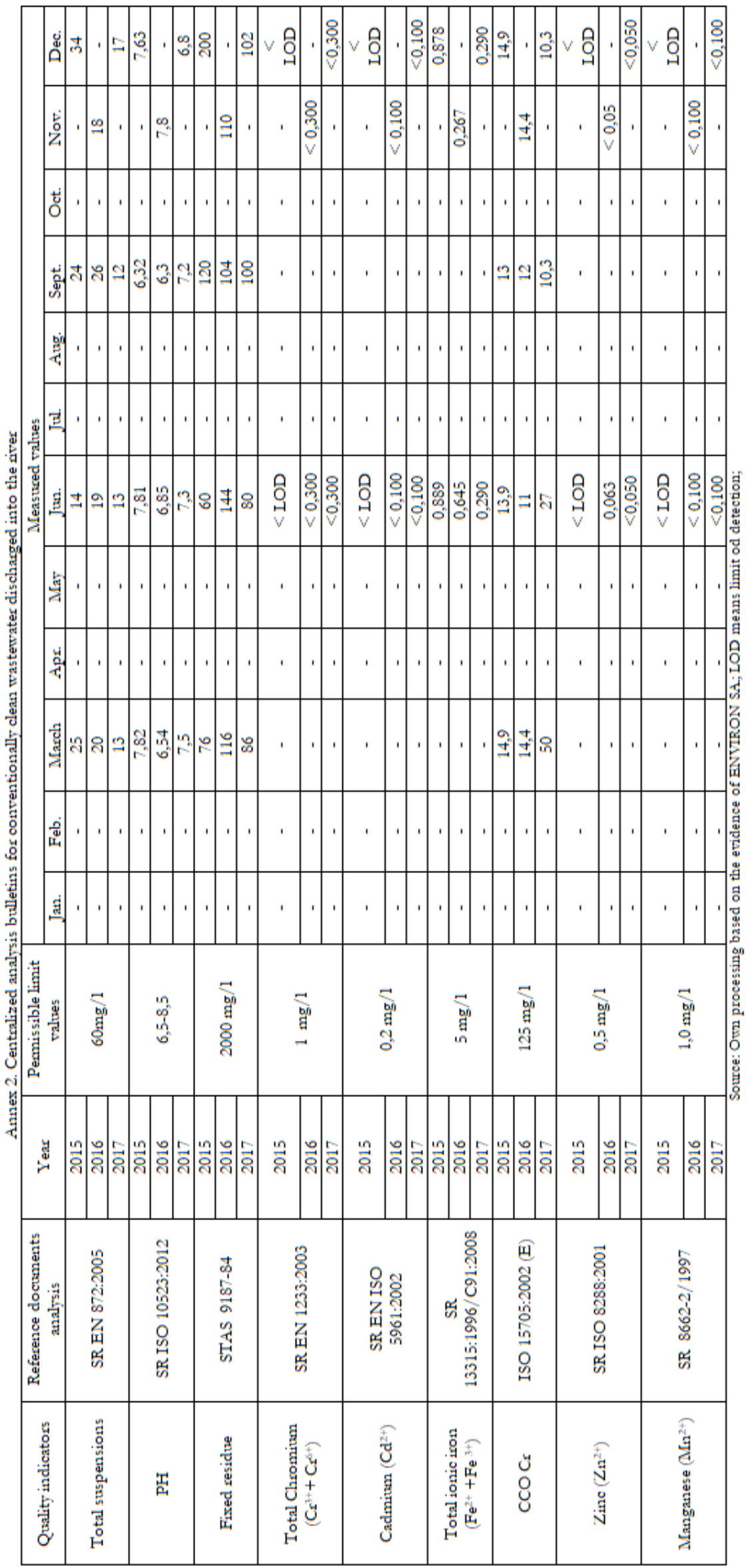




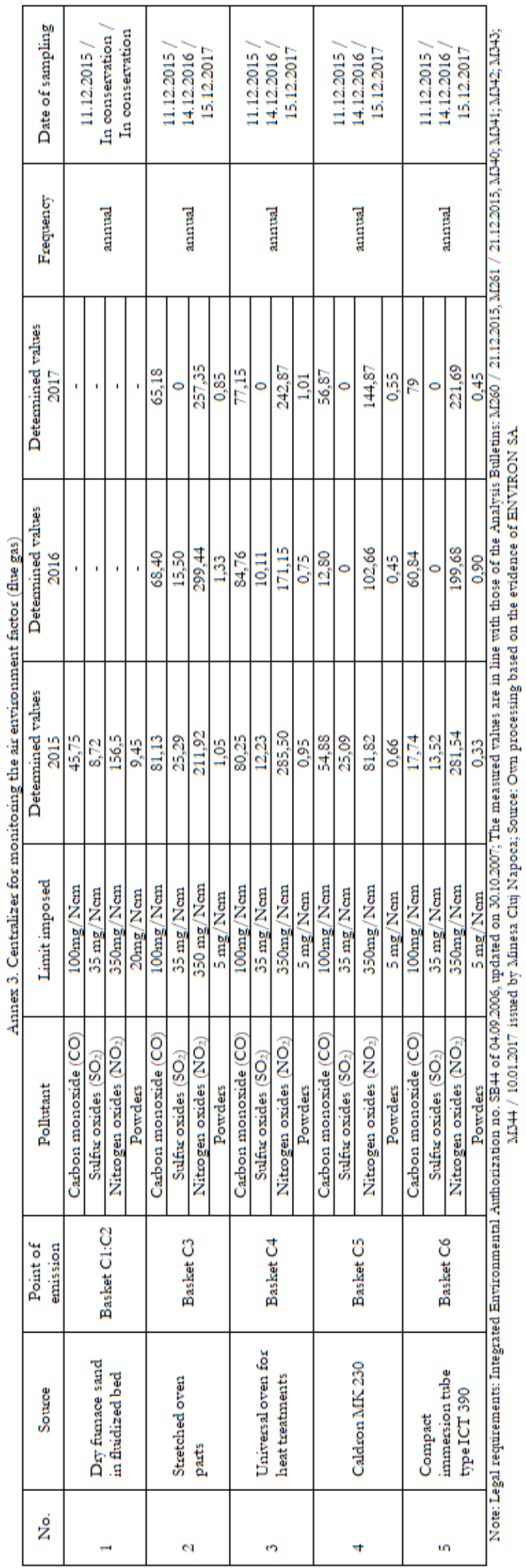




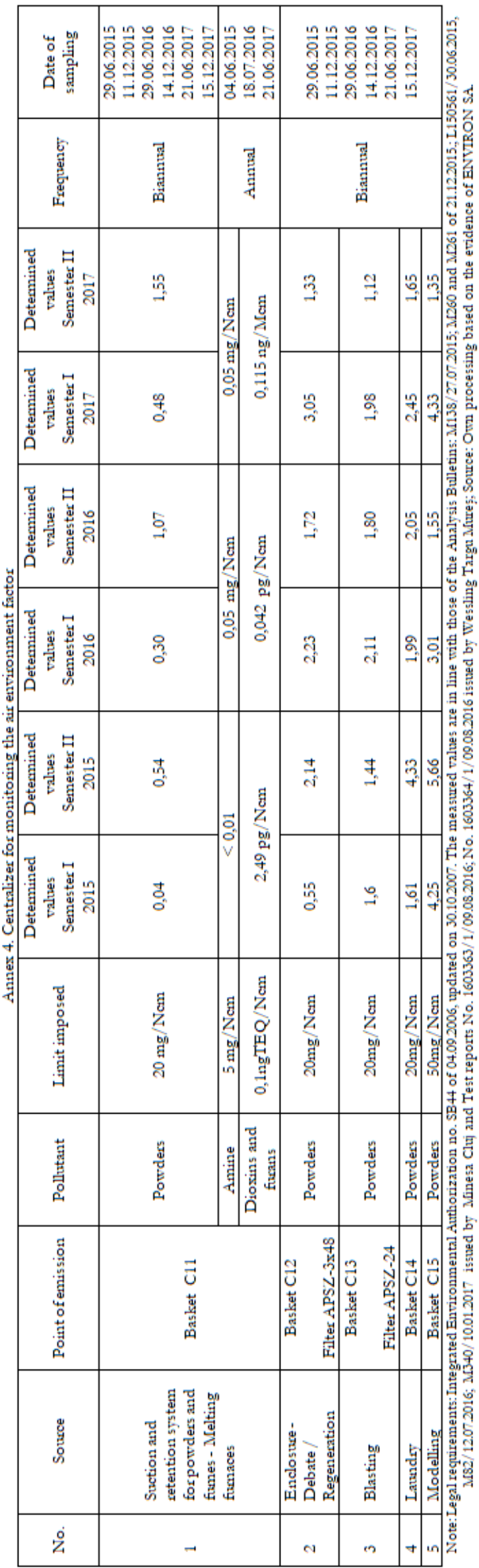

